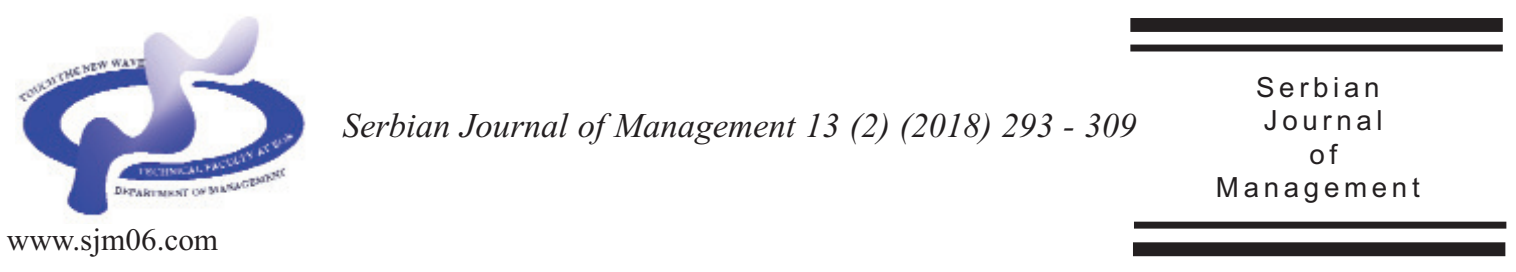

\title{
KNOWLEDGE MANAGEMENT IN THE PUBLIC SECTOR - THE CASE OF SERBIAN LOCAL GOVERNMENT
}

\author{
Zorica Mitrović*, Vladimir Obradović and Milija Suknović \\ University of Belgrade, Faculty of organizational sciences, \\ Jove Ilića 154, Belgrade, Serbia
}

(Received 15 September 2017; accepted 5 April 2018)

\begin{abstract}
Knowledge has become an increasingly important determinant of competitiveness for the local governments. The purpose of this paper was to explore the existence of knowledge management (KM) in Serbian local government (LG) and to identify and analyzes processes and infrastructure that supports KM practices. The paper consists of two parts; the first part covers comprehensive literature review that summarizes the existing research done on the subject of knowledge management in public sector in order to put research in context and to highlight the contribution of this paper to the existing body of knowledge. The second part consists of empirical research conducted to get a preview of the current state of the KM practice in Serbian local government. There were several important findings regarding KM practices in Serbian LGs identified in the study, i.e., public servants have a positive attitude toward KM concept; KM activities are mostly technology supported; KM is perceived as a management priority; there is not any formal attribution of responsibility for knowledge practice to executive staff, human resource unit or IT unit, neither any mention of knowledge capacity development in strategies or plans of LGs. Finally, the results of this research study provide valuable guidance for future research for both academics and practitioners.
\end{abstract}

Keywords: knowledge management, knowledge management processes, local government

\section{INTRODUCTION}

Today, knowledge management (KM) is increasingly recognized as an important resource for public sector organizations.
Regardless of the importance, public sector organizations are yet to explore the benefits of knowledge management application in their practices. One of the reasons of the lack of the research in this field is that knowledge

\footnotetext{
* Corresponding author: zorica.mitrovic@fon.bg.ac.rs
}

DOI: 10.5937/SJM13-15037 
management is such a broad construct, on the one hand, its boundaries are not very clear (what does it cover and what not?), and on the other hand, it may not be recognizable in a similar way among people in practice. KM, for example, includes many elements with which we are familiar for long, such as human resources aspects like training employees, involving employees in process improvements and sharing information on the job, but it also seems to include the application of modern tools of information technology for building up knowledge in organizations.

The purpose of this paper is to trace the existence of KM in Serbian local government and identify and analyzes processes and infrastructure that supports KM practices. The main argument of this paper is that knowledge management is increasingly important for local governments and that lack of systematic approach to knowledge management capacity development could make it more difficult to improve their performances and compete in the increasingly competitive environment. Further, this study seeks to raise awareness of the importance of knowledge management and its potential to support local governments (LG) in improving their performances. The first step in this direction and the purpose of this paper is to conduct the study and assess the current state of knowledge management practice in the context of Serbian local government.

Section 1 contains some general definitions of knowledge management terms and identifies knowledge management elements as a basis for study design. Further, besides general consideration of knowledge management, Section 1 consists of three parts. The first part covers a review of role and application of knowledge management in public sector; the second part is specifically oriented to opportunities and challenges in the context of local governments, while the third covers context of Serbian public sector and Serbian local government background.

Section 2 presents the literature review on the research topic.

Section 3 presents study design for research conducted for the purpose of this paper. The results of the study, as well as findings and discussion are summarized in Section 4 and 5. Finally, Section 6 draws some conclusions on the subject of this paper, i.e. weather there is knowledge management and what practices took place in Serbian local governments.

\section{LITERATURE REVIEW}

In general, knowledge management is a complex concept. Peter F. Drucker was the first who used the term "knowledge worker" back in 1959. Many years later, in the 1990s, knowledge management emerged as a hot topic in the business sector, later followed by public sector organizations.

The literature review showed various attempts of scholars to define concept and perspectives of knowledge management. However, many authors agree that there is no clear consensus on the definition of KM. On the other side, the consensus is achieved about knowledge management as a systematic approach that improves organizations performance (Murray, 2002; Marques \& Simon, 2006; Choi et al., 2008; Akdere, 2009; Ho, 2009; Gholami et al., 2013; Todorovic et al., 2015). One widely used definition of KM is the one by Nicolas (2004) that describes KM as a systematic process of creating, acquiring, 
disseminating, leveraging and using knowledge to achieve competitive advantage.

The very concept of knowledge can refer to many different forms. Knowledge could be defined as a combination of experiences, values, contextual information and expert insights that enable organizations to evaluate and absorb new experiences and information (Davenport \& Prusak, 2000). Further, the knowledge to be managed includes both explicit and tacit knowledge. Tacit knowledge is difficult to articulate or communicate, and typically resides in a human mind, it is deeply rooted in action, commitment, and involvement in a particular context (Nonaka, 1994). On the other hand, explicit knowledge refers to knowledge that has been captured in some tangible forms, and the knowledge that is transmittable in formal, systematic language (Nonaka, 1994). In order to manage the knowledge, organizations need to understand the process of knowledge creation (combination, internalization, socialization, and externalization) through conversion between tacit and explicit forms.

Lastly, organizations need to build knowledge capabilities that will enable organizations to utilize created knowledge in integrated knowledge processes to achieve superior performances. In order to create knowledge capabilities organizations need infrastructure capabilities ( $\mathrm{Wu} \& \mathrm{Hu}, 2012$ ) or knowledge enablers (Noh et al., 2014). Basically, the same term for organizational structures is key to the success of a knowledge management processes. These include technology, structure, and culture (Gold et al., 2001). Various researchers investigated the relationship between these elements and knowledge management process (Adeoti, 2002; Noh et al., 2014; Pee
\& Kankanhalli, 2015). The research methodology used in these papers will be the basis for study design in this paper.

As for knowledge management application in the public sector, there is a growing body of knowledge in this field. The next subsections cover the subjects knowledge management in public sector with respect to local government context and some general observations about Serbian public and local government context.

\subsection{Knowledge management in Public Sector}

For two decades now, knowledge management $(\mathrm{KM})$ is the prominent and important topic in the public sector management literature. From the strategic perspective, globalization and the ICT sector development were two key trends that influenced governments and their organizations to introduce knowledge management practices to met competitive challenges (King \& Zeithaml, 2003; Sotirakou \& Zeppou, 2004). Additionally, the pressure was high due to the role that public sector organizations had in creating the necessary conditions and infrastructure for private sector effectiveness at all three levels, national, regional and local (Hartley \& Skelcher, 2008). As a response to this increasing pressure, during the early 2000s governments started initiation phase and launched knowledge management initiatives to improve efficiency and effectiveness in public sector organizations.

Today, in most of the developed countries $\mathrm{KM}$ is a well-established management tool that runs governments' performances (McAdams \& Reid, 2000; Riege \& Lindsay, 2006; Yao et al., 2007). These countries are highly aware of the importance of sharing 
knowledge across government organizations, and knowledge management has been given high priority. On the other hand, there is growing body of literature that shows examples of knowledge management practices in different sectors such as education (Edge, 2005), police (Seba \& Rowley, 2010), health sector (Van Beveren, 2003), but also research on specific aspects of knowledge management framework such as collaboration and networking (Dawes et al., 2009), organizational learning and knowledge sharing (Yao et al., 2007; Rashman et al., 2009; Titi Amayah, 2013), and relation between KM and organizational performance (Pee \& Kankanhalli, 2015).

This increasing interest in the use of knowledge management in the public sector is associated with improved efficiency, cost reduction and improved quality (McAdams \& Reid, 2000). On the other hand, (Wiig, 2002) studied the role of knowledge management in building society's intellectual capital to improve the effectiveness of public decision-making and situation handling. More recently, (Pee \& Kankanhalli, 2015) literature review showed that knowledge management found to be instrumental in policy development, law enforcement, crisis and disaster management, health and human services, and electronic government. There are, however, some challenges associated with successful implementation of knowledge management practice in the public sector. Lastly, public administration tasks and services are being perceived as knowledge-intensive in nature and excelling in KM can potentially enhance public organizations' effectiveness.

In the local government's context, knowledge management is the relevant but insufficiently researched field. And at this point, local governments are facing a various and complex challenges, what make knowledge management become the increasingly important topic of debate for both academics and practitioners. The literature review on the specifics of the knowledge management in the context of local governments in presented in the next part of this section.

\subsection{Knowledge management in Local Government}

In general, the LGs are turning to knowledge management as a response to increasingly challenging global environment and as a solution to cope with ever-present pressure from central governments to improve efficiency and to increase the quality of the service (Sivarajah et al., 2015). On the other side, implementation of KM is particularly challenging because of characteristics of public sector organizations, i.e., bureaucratized organizational structures, organizational culture and collaboration challenges, need for specific ICT infrastructure and at last but most important the role of people in making KM work. In short, knowledge management in local government setting requires deeply understanding of the context of the public sector.

Regarding challenging global environment, increasing globalization made local governments an important economic player. The additional circumstance was that in the post-industrial economy, natural resources, capital, and labor were being replaced by knowledge as the essential resource (Drucker, 1993). As a consequence, LG needed "knowledge" to fast-adopt and competed in the ever-changing global environment. Even further, knowledge management (KM) was considered as 
essential to all governmental agencies at the national, regional or local levels because governmental organizations are knowledgebased organizations (Yuen, 2007).

Fiscal pressures were the second important circumstance that globally influenced local governments. Since the 1990s, frequent attempts at higher levels of government to put fiscal stress on local authorities have emerged all over the world (Bovaird et al., 1996). The aim of central governments was to seek greater efficiency by reducing expenditures mainly through the achievement of economies of scale, and through a better allocation of resources, bringing government functions closer to citizens (Galariotis et al., 2016). Additionally, KM was recognized as a powerful instrument that enables public sector organizations to increase efficiency and deal with this pressure (McAdams \& Reid, 2000).

As already motioned, LGs were using knowledge management to met government's expectation and increase the quality of the service. Besides governments, customers were also increasingly demanding higher service quality. As a consequence, the goal of many LG was to use the advantage of knowledge management to improve the service delivery. Luen and Al-Hawamedeh (2001) noticed that knowledge management was a natural solution to improve operations and enhance customer service. At the same time, knowledge also served as a mechanism through which the citizens could value the decision-making processes and quality of service delivery (Svaärd, 2014).

In the 2000s, service delivery as well as dealing with local public issues were closely related to the use of information and communication technology like egovernment and e-democracy (Bovaird \&
Löffler, 2002). Some researchers even indicated that advancement of computers and information technology (IT) had changed the way the services are delivered (Chelliah et al., 2016). Same authors recognized eGovernment as an opportunity for LG to improve the efficiency of services and information provided to citizens, businesses, employees, and government agencies.

In the second decade of 21 st century, the challenge has been even bigger with EU running the digital agenda and the concepts like cloud computing (Maresova \& Kacetla, 2015). Accordingly, LG recognized new technologies like Web 2. as opportunities for further development. For example, this second generation of web services provides a social and participatory virtual platform for LG to collaborate, network and interact with stakeholders (Sivarajah et al., 2015).

While knowledge management is considered as the opportunity for LG to gain competitive advantage, KM implementation is particularly challenging because of characteristics of public sector organizations (Massaro et al., 2015). For one, public sector organizations are highly bureaucratized structures (Dewah \& Mutula, 2014) and culturally there is no tradition of sharing information. On the other hand, to fully utilize the organizations' capability to capture, use and share knowledge, LG had to move towards more flexible and horizontal models of organizations and away from centralization (Ansari et al., 2012). For public sector organizations, aspiring for 24hour responsiveness to a range of stakeholder needs, this creates a practical challenge of balancing 'responsible' administration and 'flexibility,' suggesting more discretion in decision-making and rules, more autonomy and loosely defined positions (Pratt, 2013). 
Furthermore, many researchers singled out the organizational culture as one of the most important factors of successful knowledge management implementation (Davenport \& Prusak, 2000). However, developing a KM culture within the public sector is more challenging than in the private sector (Edge, 2005). It includes shaping the public servant's values, attitudes and behavior toward knowledge management practices (Douglas, 2010). The way the officials in LG generate, manage and use knowledge is crucial to its efficient management. Accordingly, Chong and Choi, (2005) noticed that besides knowledgefriendly culture, important factors in implementing knowledge management successfully are: employee training, the involvement of employees, the open and trustworthy spirit of teamwork, empowerment, visible top management and commitment, etc. Recognition of these factors as important put individuals, their involvement, and training, in the center of the knowledge management concept and emphasize human resource contribution as essential for the efficient execution of knowledge management.

In a way, collaboration amongst LG is nothing new. The networks have existed and have always played an important part in service delivery, but the formalization of these networks in recognition of their potential for knowledge sharing is relatively new. As LG started increasingly use information technology to collaborate with one another, there was a greater chance to share and use their knowledge. In the same time, wide across public sector, transnational knowledge networks were being formed to facilitate knowledge sharing across national boundaries and collaboration on critical global issues (Pee \& Kankanhalli, 2015).
Monitoring of these activities revealed that the success of these networks depended on organizations' knowledge management capabilities, information sharing tradition, information management skills of the municipal employees and attitudes toward collaboration (Dawes et al., 2009; Svaärd, 2014). Accordingly, learning within and between organizations and the sharing of knowledge was recorded to be central to the processes of public service improvement (Rashman et al., 2009).

In addition to appropriate organizational structure, organizational culture and collaboration activities, LG need appropriate ICT infrastructure to enable effective execution of knowledge management. Ansari et al., (2012) summarized criteria of IT element that has been necessary for knowledge management: access to network infrastructure and hardware, access to applied software, flexibility, and IT employees.

Finally, the literature review showed that it is the people who were central to knowledge management. This is because the knowledge is primarily in the minds of public servants, executive staff, and political leaders. On one side, public sector organizations are facing the challenge of recruiting and retaining qualified personnel either at present or likely to appear in a few years' time; and of critical skills shortage or risk of lagging professionalism (Äijälä, 2001). On the other side, there is staff discontinuity because of transfers, deaths, dismissals, and sizing (Rashman et al., 2009). But even more knowledge management brought new opportunities through changes in the structures and methods of human resource management. For example, in the new setting that permits the knowledge sharing, the expert's power is 
founded on his/her ability to make colleagues' knowledge or opinions "flexible" and so improve decision-making processes (Saussois, 2003).

In conclusion knowledge management in the context of local governments gives the opportunity to create competitive advantage and to cope with different pressures injected both globally and locally, but also presents a great challenge for LGS faced with various constraints inherent for the public sector in general. For developing countries like Serbia, both challenges and opportunities are even more complex. Some of these contextual factors are exposed in the following text.

\subsection{Knowledge management in the context of Serbian local governments}

To discuss the knowledge management in the context of Serbian local government, some level of understanding of Serbian public sector background is needed. On the other side, in detail background review is out of the scope of this paper, so just a few facts are important to mention.

First, the Government of the Republic of Serbia faces many complex policy challenges as the country pursues public administrative reform (Mihic \& Obradovic, 2012). One of the priorities of reform agenda is to improve the efficiency, effectiveness, transparency and accountability of the public administration at both central and local level. Second, in many cases, the circumstances facing the local governments are more challenging than ones on the central level and local authorities had to put additional efforts to overcome this challenges, i.e., decentralization of LG in Serbia and the likelihood of significant changes in available resources for many LG due to the changes in
Law On Local Government Finance in Serbia, etc. This and other circumstance focused local governments reform initiatives on efficiency and effectiveness improvement (Mihic \& Obradovic, 2013). As a result, progress was achieved in the area of professionalization, but further reform efforts are required for the development of merit-based and professional human resources service. Also, progress was achieved in the area of modernization, i.e., egovernment is introduced to enable more efficient and effective provision of public services to citizens, companies, and other organizations.

Third, regarding knowledge management in Serbian local governments, over the years as a part of reform initiatives, different initiatives took place to develop capacities of local governments and many of them included knowledge management components, but neither was primarily focused on creating knowledge infrastructure or knowledge management system. Consequently, the level of development of knowledge management in Serbian LG, as well as their perception of the importance of the knowledge for the development of municipalities, is not in any capacity diagnosed today. Further, all local governments in Serbia had very similar incentives, but different management capacities to implement knowledge management practices; although the knowledge-intensity of the activities of LG was increasing over the time, there was a constant need for highly educated and trained staff and good strategies for knowledge sharing within LG, what was a big challenge for public sector in general; for successful implementation of KM initiatives, the public sector should operate in an environment in which promotes transparency 
and cooperation with the aim to make knowledge widely accessible, what was not the case in the context of Serbian local governments; KM initiatives in the LGs in Serbia are still based on individual efforts instead of developing a joint strategy and approach to knowledge management, etc.

Finally, there is lack of any research study that could shed light on knowledge management in Serbian LGs. Due to this fact, it would be of most importance to make the first assessment of where local governments stand regarding knowledge management; what is the level of development of knowledge management capacity; what is the perception of the importance of the knowledge for the development of Serbian LGs. The next section presents the study design.

\section{STUDY DESIGN}

A pilot study was conducted to get a preview of the current state of the knowledge management practice at local governments level. The pilot study was carried out as pretesting for the major study that will include all LGs in Serbia. The data collection method involved a questionnaire with 53 questions. The survey was divided into two sections. The first part consisted of questions regarding knowledge management infrastructure. The second section consisted of questions regarding knowledge management processes. The questions were fixed with the possibility to select only one answer or to grade answers using the 5-point Likert-type scale of importance. The results were processed using the software package SPSS Statistics 20.

The questionnaire was distributed to 55 LG. All the LG were contacted through a phone call, and a questionnaire was sent via mail. A total of 30 out of 55 LG completed and returned questionnaire (response rate of $55 \%$ among selected LG). Therefore, the sample included $21 \%$ (30 out of 145) of Serbian LGs. The sample consisted of only one respondent per LG unit. The respondents were municipalities' managers or its deputies.

Based on the indicator of economic development of the LG units (EDI) ${ }^{1}$, the sample was divided into two groups: developed and undeveloped LG units. The first group included 17 LG (55\%), which is based on EDI classified in the first and second group. The second group included 13 LG (45\%) that are based on EDI categorized in the third and fourth group, including divested LG.

Finally, the reliability test was conducted using Cronbach alpha reliability to ensure consistency of the data collected. The Cronbach alphas of separate dimensions are 0.705 (technology dimension), 0.727 (organizational culture), 0.817 (human resource), 0.859 (knowledge acquisition) and 0.783 (knowledge sharing). The results are reported in Table 1. The values for all the dimensions were more than 0.7 indicating high internal consistency.

Table 1 - Analysis of internal consistency of knowledge dimensions (Reliability analysis)

\begin{tabular}{llcc}
\hline & Dimensions & Number of items & Cronbach's alpha \\
\hline INFRASTRUCTURE & Technology & 8 & 0.705 \\
& Organizational culture & 6 & $0.727^{*}$ \\
& Human resource & 7 & $0.817^{*}$ \\
PROCESSES & Knowledge acquisition & 10 & 0.859 \\
& Knowledge sharing & 6 & 0.783 \\
\hline
\end{tabular}

${ }^{*}$ Cronbach's alpha after the items are deleted

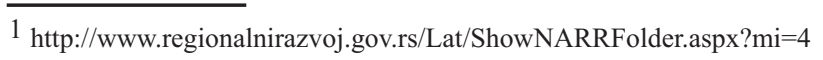




\section{RESULTS}

Results section illustrates the evaluation of knowledge infrastructure, knowledge processes, and overall knowledge management capacities and difference concerning these elements between LGs classified as developed and underdeveloped.

The study measured the level of development of knowledge management infrastructure and knowledge management processes in LGs. The measurement of knowledge management infrastructure included four dimensions: structure, technology, human resource and organizational culture. The structure was evaluated on binary scales using 12 items, analyzing the existence of each item in every LG. The total score for this dimension is calculated and then standardized to 5-point scale to ensure that all variable are measured using the same scale. Technology dimension was measured using eight items, human resource seven items, and organizational culture six items. These three dimensions were evaluated using the 5-point Likert-type scale of importance. Knowledge management processes measurement included two dimensions: knowledge acquisition and knowledge sharing. Knowledge acquisition dimension is measured using ten items. Knowledge sharing dimension is measured using six items. These two dimensions were rated on a 5-point Likert scale. The total score for dimensions that used 5-point scale was calculated as the average value of items included in each dimension.

Descriptive statistics for all study variables are presented in Table 2. For three out of four dimensions (culture, structure, technology) the average value of knowledge management infrastructure was higher in developed LGs. On the other hand, the average value of human resource dimension was almost the same for both developed (2.86) and undeveloped (2.87) LGs. The biggest difference between these two groups was in structure dimension. Developed LGs have the average value of structure dimension 3.74 while underdeveloped LGs' structure dimension is evaluated with 2.85 .

For both dimensions of knowledge processes, knowledge acquisition and knowledge sharing the average value was higher in developed LGs. However, it is

Table 2 - Descriptive statistics for knowledge dimensions

\begin{tabular}{|c|c|c|c|c|c|}
\hline \multirow{5}{*}{ Developed } & \multirow{5}{*}{$\begin{array}{l}\text { Mean } \\
\mathrm{N} \\
\text { Std. Deviation }\end{array}$} & \multicolumn{4}{|c|}{ Knowledge Infrastructure } \\
\hline & & Culture & Structure & Technology & HR \\
\hline & & 3.87 & 3.74 & 3.86 & 2.86 \\
\hline & & 16 & 16 & 16 & 16 \\
\hline & & 0.69 & 0.97 & 0.65 & 0.78 \\
\hline \multirow[t]{3}{*}{ Underdeveloped } & Mean & 3.76 & 2.85 & 3.56 & 2.89 \\
\hline & $\mathrm{N}$ & 14 & 14 & 14 & 14 \\
\hline & Std. Deviation & 0.49 & 1.24 & 0.70 & 0.81 \\
\hline \multirow[t]{3}{*}{ Total } & Mean & 3.82 & 3.33 & 3.72 & 2.87 \\
\hline & $\mathrm{N}$ & 30 & 30 & 30 & 30 \\
\hline & Std. Deviation & 0.59 & 1.17 & 0.68 & 0.78 \\
\hline \multirow{5}{*}{ Developed } & & \multicolumn{4}{|c|}{ Knowledge processes } \\
\hline & & \multicolumn{2}{|c|}{ Knowledge Acquisition } & \multicolumn{2}{|c|}{ Knowledge Sharing } \\
\hline & Mean & \multicolumn{2}{|c|}{3.13} & \multicolumn{2}{|c|}{3.43} \\
\hline & $\mathrm{N}$ & \multicolumn{2}{|c|}{16} & \multicolumn{2}{|c|}{16} \\
\hline & Std. Deviation & \multicolumn{2}{|c|}{0.70} & \multicolumn{2}{|c|}{0.73} \\
\hline \multirow[t]{3}{*}{ Underdeveloped } & Mean & \multicolumn{2}{|c|}{2.94} & \multicolumn{2}{|c|}{3.02} \\
\hline & $\mathrm{N}$ & \multicolumn{2}{|c|}{14} & \multicolumn{2}{|c|}{14} \\
\hline & Std. Deviation & \multicolumn{2}{|c|}{0.76} & \multicolumn{2}{|c|}{0.88} \\
\hline \multirow[t]{3}{*}{ Total } & Mean & \multicolumn{2}{|c|}{3.04} & \multicolumn{2}{|c|}{3.24} \\
\hline & $\mathrm{N}$ & \multicolumn{2}{|c|}{30} & \multicolumn{2}{|c|}{30} \\
\hline & Std. Deviation & \multicolumn{2}{|c|}{0.72} & \multicolumn{2}{|c|}{0.81} \\
\hline
\end{tabular}


Table 3 - Descriptive statistics for Knowledge management capacities

\begin{tabular}{llcc}
\hline & & Knowledge Infrastructure & Knowledge Processes \\
\hline Developed & Mean & 3.58 & 3.35 \\
& $\mathrm{~N}$ & 16 & 16 \\
& Std. Deviation & 0.46 & 0.55 \\
\hline Underdeveloped & Mean & 3.26 & 3.23 \\
& $\mathrm{~N}$ & 14 & 14 \\
& Std. Deviation & 0.47 & 0.57 \\
\hline Total & Mean & 3.43 & 3.29 \\
& $\mathrm{~N}$ & 30 & 30 \\
& Std. Deviation & 0.48 & 0.55 \\
\hline
\end{tabular}

noted the slightly higher difference between developed and undeveloped LGs for knowledge sharing dimension (0.19), than for knowledge acquisition dimension (0.9).

The overall knowledge management capacities of LGs measurement included two elements knowledge infrastructure and knowledge processes (Table 3). For both elements, knowledge infrastructure and knowledge processes, the knowledge management capacities are more developed in developed than in underdeveloped LGs. The difference is slightly higher for knowledge infrastructure (0.32) than for knowledge processes $(0.12)$.

\section{FINDINGS AND DISCUSSION}

Evaluation of knowledge infrastructure and knowledge processes showed that there is no significant difference between developed and underdeveloped LGs regarding knowledge management capacities. Considering the fact, findings and discussion are provided without considering development difference between LGs. Also, to capture the important details of knowledge management practice in Serbian LGs, findings, and discussion are focused on items used for evaluation of knowledge infrastructure and knowledge processes.
Finally, the section provides just the most important findings, and it is organized to show the most significant findings regarding knowledge management practices in LGs and regarding the perception of the importance of knowledge management for the successful development of LGs.

\subsection{Knowledge Management Practice In LG In Serbia}

The challenges of knowledge management application in LG context are varied and complex. The KM literature showed that LGs are considering $\mathrm{KM}$ as a way to enhance efficiency and service delivery. In the case of Serbian LGs, the situation regarding general views towards knowledge management is positive but mostly challenging.

First, public servants have a positive attitude toward knowledge management concept. About 46 percent of respondents consider that staff has a positive attitude toward knowledge sharing. However, only $50 \%$ of respondents are spontaneously organizing knowledge events, such as meetings or sharing the documents as their initiatives. The perception of managers' behavior by staff towards knowledge-based culture is critical. 
Respondents considered that managers are insufficiently involved in taking the lead in developing knowledge culture, only 37 percent of respondents thought that "managers are increasingly involved in information dissemination to the staff."

Second, the technology infrastructure is in the poor state. About 70 percent of the staff has Internet access, and about 63 percent have access to Intranet. Also, the poor technology infrastructure provision is recorded in the field of training in using the ICT and IT resource management. Just 44 percent of $L G$ is providing training for all their staff, and only 63 percent of LGs have introduced IT department.

All LGs have an Internet site, but qualities of data available and regular updating are on a moderate level. The average rate of quality aspects of Internet site evaluated by respondents was 3.97 out of 5 .

eGovernment service in LGs' authority is relatively developed. In 97 percent of LGs, service users have a possibility of downloading administrative forms and applications, in 70 percent possibility to fill in administrative forms electronically and in 53 percent to make full transaction including payments online.

Further, institutional capacities necessary for the support of knowledge management practices are moderately developed. More than $60 \%$ of LG are still perceived as highly centralized organizations. The officer/unit for information management is introduced In 43 percent of LG. The ISO 9000 is present in 9 out of 30 LG units, what is about 30 percent. Plan/strategy for eGovernment improvement is developed in 37 percent of LG. While only $30 \%$ of LG developed the Policy/Strategy with information management, human resource, and organizational aspects. The more than half of the LG has the budget for training (60 percent).

Finally, the most important finding is that in Serbian LGs knowledge management processes are mostly in the development phase. Most of the identified knowledge activities are the regular ones, already existing, but now recognized as the source of knowledge, while the other ones have been caused by technology improvements.

For example, it is noticed that LGs uses informational meetings, quality review meetings, peer review events and other types of events as a way of acquisition and sharing knowledge. Informational meetings are most frequent for of activity, about 73 percent respondents use it frequently or very frequently.

On the other side, technology developments such as Intranet, internal portals, conventional databases as well as document management systems provided access to knowledge and enabled the knowledge sharing. Between 63 and 80 percent of all LGs uses one or more of these technology solutions.Further, as an external source of knowledge LGs identified knowledge networks like regional associations of LG or professional bodies and associations, but also universities, research centers, civil sector organizations as well as private and consulting firms. It is interesting to notice that about 60 percent of LGs used most frequently publications or data from civil sector organizations.

Lastly, besides training, different human management practices are identified such as mentoring and coaching. About 60 percent of LG provides up to 5 days of training on a yearly basis. Accordingly, about 71 percent of respondents indicated that $\mathrm{LG}$ is encouraging staff to attend training. On the other hand, the practice of mentoring and 
coaching are developed in less than 50 percent of LGs.

\subsection{Perception Of Importance Of Knowledge Management For The Successful Development Of Local Governments}

One of the aims of the research was to examine do LGs perceive the knowledge management as an important concept for development of local governments. The literature review showed that the essential resource that will enable public sector organizations to achieve the competitive positions is knowledge. In order to achieve that, public sector organizations need to manage their knowledge.

Several components could indicate the perception of the importance of knowledge management in specific LGs, i.e., whether knowledge management is perceived as a management priority. In the case of Serbia, it is noted that only 57 percent of respondents considered knowledge management as one of top management priorities in LGs.

As a consequence, there is not any formal attribution of responsibility for knowledge practice to executive staff, human resource unit or IT unit. Exceptions are LGs that introduced an organizational unit or officer responsible for information/knowledge management (about 40 percent).

Further, the introduction of knowledge management in plans and strategies in the organization cloud indicate the perception of knowledge management as important. In the case of Serbian LGs, only about 32 percent of LGs have any element of knowledge capacity development put in strategies or plans of LGs.

Still, respondents do think that knowledge sharing is important. Whopping 97 percent of interviewees from LG (strongly agree and agree) considered that "knowledge sharing with the other LGs units would increase the efficacy of LG." Also, 84 percent of respondents from LGs (strongly agree and agree) considered that "knowledge sharing would minimize duplication of efforts between different LGs units." However, as it is already noticed, only $50 \%$ of respondents are spontaneously organizing knowledge events, such as meetings or sharing the documents as their initiatives. This all indicates that even though respondents think that knowledge management is important, they are not ready to practice it informally.

\section{CONCLUSION}

This is the first research study conducted in Serbian LG investigating knowledge management capacities. In the first part of the paper, the theoretical background was presented for the purpose of considering the importance of the knowledge management in the context of the public sector and local governments. This literature review provided a solid argument for challenges and opportunities laid in front of public sector organizations and especially local governments seeking for better performances and development of capacities to overcome the constant pressure for efficiency improvement, globalization pressures, etc. Even though different initiatives took place to develop capacities of Serbian LGs and many of them included knowledge management components, neither was primarily focused on creating knowledge infrastructure or knowledge management system. Consequently, there was a lack of information on the level of development of knowledge management in Serbian LGs and 
perception of the importance of the knowledge for the development of municipalities. The purpose of this study was to make the first evaluation of where local governments in Serbia stand regarding knowledge management.

Further, the second part of the paper consisted of study design, results and detailed discussion on findings. The study was designed as a pilot study, carried out as pre-testing for the major study that will include all LGs in Serbia. It was a singlemethod study, the data collection method involved a questionnaire with 53 questions. The sample included 21\% (30 out of 145) of Serbian LGs. Results section presented the evaluation of knowledge infrastructure, knowledge processes, and overall knowledge management capacities and difference concerning these elements between LGs classified as developed and underdeveloped.

First, the most important result of the study was that there is no significant difference between developed and underdeveloped LGs regarding knowledge management capacities. Second, there were several important findings regarding knowledge management practices in Serbian LGs identified in the study, i.e., public servants have a positive attitude toward knowledge management concept, but they also perceive that managers' behavior towards knowledge-based culture is unsatisfactory. On the other side, to develop knowledge capacities, LGs has to put significant effort in preparation of staff for the digital economy. These include the development of competencies databases (only $40 \%$ of LGs has it), the popularization of lifelong learning concept and the introduction of incentives regarding the reward for knowledge and information sharing. Further, the technology dimension is critical. Knowledge management activities are mostly technology supported. LGs with poorly technology infrastructure, especially with poor performances regarding access to networking infrastructure or lack of IT support, hardly could address future challenges. Also, knowledge management processes are strictly based on already existing practices. The LGs need to identify and introduce the new methods to respond to new knowledge intensive activities.

Third, the study showed that knowledge management is perceived as a management priority (57 percent of respondents). But, with some exceptions, there is not any formal attribution of responsibility for knowledge practice to executive staff, human resource unit or IT unit, neither any mention of knowledge capacity development in strategies or plans of LGs. Also, respondents do think that knowledge sharing is important, but they are not ready to practice it informally.

Finally, the results of this research study provided valuable guidance for future research. First, there are a very limited number of studies in this field. This is especially the case in Serbia, where this type of research is done for the first time. This study used one method to measure the knowledge management capacities of LG. Further research should include the multimethod research that will combine qualitative and quantitative methods. Also, a conceptual framework for measurement of knowledge management capacities in LG should be developed. The testing of the reliability of different research methods could contribute to this aim. In order to ensure the impact of research results, further research should include all LG in Serbia. Also, the sample should contain at least three respondents from one LG from different 
levels of hierarchy. The further research should also include the LG from other countries to achieve wider applicability of research results.

\section{Acknowledgments}

This paper is a result of Strategic Project founded by Ministry of Education and Science of republic Serbia: Exploring modern trends of strategic management of the application of specialized management disciplines in the function of the competitiveness of Serbian economy, No 179081.

\section{References}

Adeoti, J.O. (2002). Building technological capability in the less developed countries: the role of a national system of innovation. Science and Public Policy, 29 (2), 95-104.

Akdere, M. (2009). The Role of Knowledge Management in Quality Management Practices: Achieving Performance Excellence in Organizations. Advances in Developing Human Resources, 11 (3), 349-361.

Äijälä, K. (2001). Public Sector - an employer of choice? Report on the competitive public employer project. Paris: OECD Publishing.

Ansari, M., Youshanlouei, H.R., \& Mood, M.M. (2012). A Conceptual Model for Success in Implementing Knowledge Management: A Case Study in Tehran Municipality. Journal of Service Science and Management, 5(2), 212-222.

Bovaird, T., \& Löffler, E. (2002). Moving from excellence models of local service delivery to benchmarking 'good local governance. International Review of Administrative Sciences, 68, 9-24.

Bovaird, T., Davis, P., \& Green, J. (1996). More for Less: Managing Within Limited Resources. London: Local Government Management Board.

Chelliah, P.P., Thurasamy, R., Alzahrani, A.I., Alfarraj, O., \& Alalwan, N. (2016). EGovernment service delivery by a local government agency: The case of ELicensing. Telematics and Informatics, 33, 925-935.

Choi, B., Poon, S. K., \& Davis, J. G. (2008). Effects of knowledge management strategy on organizational performance: A complementary theory-based approach. The International Journal of Management Science, 36 (1), 234-251.

Chong, S.C., \& Choi, Y.S. (2005). Critical Factors in the Successful Implementation of Knowledge Management. Journal of Knowledge Management Practice, 6(6).

Davenport, T., \& Prusak, L. (2000). Working Knowledge: How Organizations Manage What they Know. Boston: Harvard Business School Press.

Dawes, S., Cresswell, A., \& Prado, T. (2009). From "Need to Know" to "Need to Share": Tangled Problems, Information Boundaries, and the Building of Public Sector Knowledge Networks. Public Administration Review, 69(3), 392-402.

Dewah, P., \& Mutula, S.M. (2014). Knowledge retention strategies in public sector organizations: Current status in subSaharan Africa. Information Development, 32(3), 362-376.

Douglas, J. (2010). The Identification, Development and Application of Information Culture in the Western Australian Public Sector. Faculty of Computing, Health, and Science; Edith Cowan University. 


\title{
УПРАВЉАЊЕ ЗНАЊЕМ У ЈАВНОМ СЕКТОРУ - СЛУЧАЈ ЛОКАЛНЕ ВЛАСТИ У СРБИЈИ
}

\author{
Зорица Митровић, Владимир Обрадовић и Милија Сукновић
}

\begin{abstract}
Извод
Знање постаје све важнија детерминанта конкурентности за локалне власти. Циљ овог рада био је истражити постојање управљања знањем (Уз) у локалној самоуправи у Србији и идентификовати и анализирати процесе и инфраструктуру која подржава праксе УЗ. Рад се састоји из два дела; први део обухвата свеобухватни преглед литературе која сумира постојећа истраживања спроведена на тему управљања знањем у јавном сектору, како би се истраживање ставило у контекст и нагласио допринос овог рада постојећим резултатима. Други део састоји се од емпиријског истраживања које је спроведено да би се добио увид у тренутно стање праксе УЗ у локалној самоуправи. Добијено је неколико важних закључака у вези са праксом УЗ у српским локалним властима идентификованим у студији. Неки од закључака су да државни службеници имају позитиван став према концепту УЗ; активности У3 су углавном подржане од стране технологије; У3 се сматра птиоритетом управљања; не постоји формално приписивање одговорности за праксу знања извршном особљу, јединици људских ресурса или ИТ јединици, нити било какво помињање развоја капацитета знања у стратегијама или плановима локалних власти. На крају, резултати овог истраживања пружају драгоцене смернице за будуће истраживање како за научне истраживаче тако и за практичаре.
\end{abstract}

Кључне речи: управљање знањем, процес управљања знањем, локална самоуправа

Drucker, P. (1959) The Landmarks of Tomorrow. New York: Harper \& Brothers.

Drucker, P. (1993). The Post-Capitalist Society. Oxford: Butterworth-Heinemann.

Edge, K. (2005). Powerful public sector knowledge management: a school district example. Journal of knowledge management, 9 (6), 42-52.

Galariotis, E., Guyot, A., Doumpos, M., \& Zopounidis, C. (2016). A novel multiattribute benchmarking approach for assessing the financial performance of local governments: Empirical evidence from France. European Journal of Operational Research, 248 (1), 301-317.

Gholami, M.H., Asli, M.N., NazariShirkouhi, S., \& Noruzy, A. (2013). Investigating the Influence of Knowledge Management Practices on Organizational
Performance: An Empirical Study. Acta Polytechnica Hungarica, 10(2), 205-216.

Gold, A., Malhotra, A., \& Segars, A. (2001). Knowledge management: An organizational capabilities perspective. Journal of Management Information Systems, 18 (1), 185-214.

Hartley, J., \& Skelcher, C. (2008). The agenda for public service improvement. In J. Hartley, C. Skelcher, C. Donaldson, and M. Wallance, Managing to Improve Public Service (pp. 3-23). Cambridge: Cambridge University Press.

Ho, C.T. (2009). The relationship between knowledge management enablers and performance. Industrial Management and Data Systems, 109 (1), 98-117.

King, A., \& Zeithaml, C.P. (2003). Measuring organizational knowledge: a 
conceptual and methodological framework. Strategic Management Journal, 44 (1), 409424.

Luen, T., \& Al-Hawamedeh, S. (2001). Knowledge management in the public sector: principles and practice in police work. Journal of Information Science, 311-318.

Maresova, P., \& Kacetla, J. (2015). Cloud Computing in the Public Sector - Case Study in Educational Institution. Procedia - Social and Behavioral Sciences (182), 341- 348.

Marques, D. P., \& Simon, F. J. (2006). The effect of knowledge management practices on firm performance. Journal of Knowledge Management, 10(3), 143-156.

Massaro, M., Dumay, J., \& Garlatti, A. (2015). Public sector knowledge management: a structured literature review. Journal of knowledge management, 19 (3), 530-558.

McAdams, R., \& Reid, R. (2000). A comparison of public and private sector perceptions and use of knowledge management. Journal of European Industrial Training, 24 (6), 317-329.

Mihic, M., \& Obradovic, V. (2012). Strategic turnaround of financial management in the Serbian government. Serbian Project Management Journal , 2 (2), 37-46.

Mihic, M., \& Obradovic, V. (2013). The role of strategic financial management in public administration in increasing the competitiveness of Serbian economy. Exploring modern trends of strategic management of the application of specialized management disciplines in the function of the competitiveness of Serbian economy, 2743.

Murray, P. (2002). Knowledge management as a sustained competitive advantage. Ivey Business Journal, 66 (4), 71-76.
Nicolas, R. (2004). Knowledge management impacts on the decision-making process. Journal of Knowledge Management, 8(1), 20-31.

Noh, M., Kim, H., \& Jang, H. (2014). Learning performance and business performance of knowledge management organizations: The moderating effect of technological capability. Information development, 30(5), 1-18.

Nonaka, I. (1994). A Dynamic Theory of Organizational Knowledge Creation. A Dynamic Theory of Organizational Knowledge Creation, 5(1), 14-37.

Pee, L., \& Kankanhalli, A. (2015). Interactions among factors influencing knowledge management in public organisations: A resource-based view. Government Information Quarterly, 33(1), 188-199.

Pratt, R. (2013). Balancing accountability and responsiveness: Building responsible flexibility in local government. In K. and. Sampson (Ed.), Public management in the blue economy. Khon Kaen: Khon Kaen University, 89-102.

Rashman, L., Withers, E., \& Hartley, J. (2009). Organizational learning and knowledge in public services organizations: A systematic review of the literature. International Journal of Management Reviews, 11 (4), 463-494.

Riege, A., \& Lindsay, N. (2006). Knowledge management in the public sector: stakeholder partnerships in the public policy development. Journal of knowledge management, 10 (3), 24-39.

Saussois, J.-M. (2003). Knowledge Management in Government: An Idea Whose Time Has Come. OECD Journal on Budgeting, 3(3), 105-136.

Seba, I., \& Rowley, J. (2010). Knowledge management in the UK police forces. Journal 
of knowledge management, 14 (4), 611-626.

Sivarajah, U., Irani, Z., and Weerakkody, V. (2015). Evaluating the use and impact of Web 2.0 technologies in local government. Government Information Quarterly, 32, 473-487.

Sotirakou, T., \& Zeppou, M. (2004). The "MATE" model: a strategic knowledge management technique on the chessboard of public-sector modernisation. Management Decision, 42 (1), 69-88.

Svaärd, P. (2014). Information culture in three municipalities and its impact on information management amidst egovernment development. International Federation of Library Associations and Institutions , 40 (1), 48-59.

Titi Amayah, A. (2013). Determinants of knowledge sharing in public sector organizations. Journal of knowledge management, 17(3), 454-471.

Todorovic, M., Petrovic, M., Mihic, M., Obradovic, V., \& Bushuyev, S. (2015). Project success analysis framework: A knowledge-based approach in project management. International Journal of Project Management, 33 (4), 772-783.

Van Beveren, J. (2003). Does health care for knowledge management? Journal of Knowledge Management, 6 (5), 420-433.

Wiig, K.M. (2002). Knowledge management in public administration. Journal of Knowledge Management, 6 (3), 224-239.

Wu, I.-L., \& Hu, Y.-P. (2012). Examining Knowledge Management Enabled Performance for Hospital Professionals: A Dynamic Capability View and the Mediating Role of Process Capability. Journal of the Association for Information Systems, 13(12), 976-999.

Yao, L., Kam, T., \& Chan, S. (2007). Knowledge sharing in Asian public administration sector: the case of Hong Kong. Journal of Enterprise Information Management, 20 (1), 51-69.

Yuen, Y.H. (2007). Overview of knowledge management in the public sector. 7th Global Forum on Reinventing Government: Building Trust in Government. Vienna: United Nations. 